\title{
Cerebral proliferative angiopathy
}

\section{Rare case of seizures, bone erosion, and pulsatile head bump}

回的

\section{Figure $\quad$ MRI and CT angiogram of cerebral proliferative angiopathy with pulsatile forehead swelling}

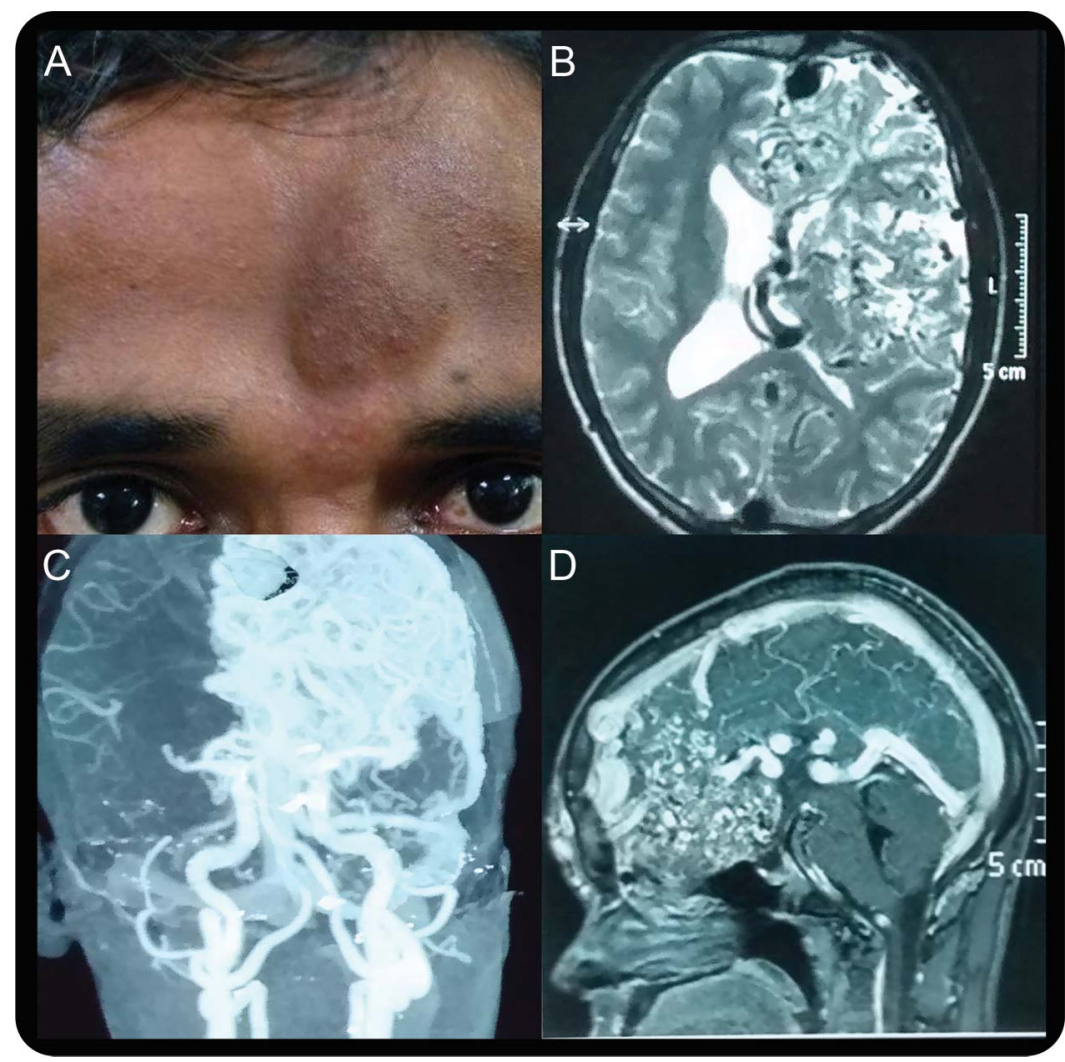

(A) Pulsatile swelling on the forehead. (B) T2-weighted axial image shows multiple flow voids in the left frontal and parietal area with intervening normal brain tissue and pressure on ipsilateral lateral ventricle. (C) CT angiogram shows extensive abnormal vascular network with multiple feeders including anterior and middle cerebral arteries. (D) Contrast MRI shows prominent sinuses and draining veins communicating with the forehead swelling.

A 22-year-old man presented with a 5-year history of focal seizures and a pulsatile bump on the forehead (figure, A; video on the Neurology ${ }^{\circledR}$ Web site at Neurology.org). He had subtle right hemiparesis with facial palsy, Mini-Mental State Examination score of 22/30, and audible bruit on forehead swelling, suggesting cerebral proliferative angiopathy (CPA). This condition differs from arteriovenous malformation in in that hemorrhages are uncommon; it has a typically large size, with normal brain parenchyma between vascular spaces (figure, B). ${ }^{1}$ There are multiple arterial feeders (figure, C) with prominent draining veins (figure, D). ${ }^{1,2}$ Embolization or surgical resections are not usually possible with a CPA diagnosis. ${ }^{1}$

Geeta Anjum Khwaja, DM, Vikram Bohra, DM, Ashish Duggal, MD, Abhilekh Srivastava, MD,

Neera Chaudhry, DM

From GB Pant Hospital, New Delhi, India.

Author contributions: Dr. Geeta Anjum Khwaja: drafting the manuscript, study concept, supervision and coordination. Dr. Vikram Bohra: drafting the manuscript, study design, literature search. Dr. Ashish Duggal: interpretation of data, acquisition of data. Dr. Abhilekh Srivastava: interpretation of data, acquisition of data. Dr. Neera Chaudhry: interpretation of data, study supervision.

Supplemental data at Neurology.org
Study funding: No targeted funding reported.

Disclosure: The authors report no disclosures relevant to the manuscript. Go to Neurology.org for full disclosures.

Correspondence to Dr. Bohra: drvikrambohra@gmail.com 
1. Lasajaunias PL, Landrieu P, Rodesch G, et al. Cerebral proliferative angiopathy: clinical and angiographic description of an entity different from cerebral AVMs. Stroke 2008;39:878-885.

2. Doria-Netto HL, deSouza-Filho AM, Doria-Netto RH, et al. Cerebral proliferative angiopathy. Arq Neuropsiquiatr 2010;68: $300-302$.

\section{It's Time to Plan for ICD-10, and the AAN Can Help}

All health care providers are required to transition to ICD-10 on October 1, 2015. Claims for services performed on or after this date with an ICD-9 code will not be processed and payments will be delayed. The AAN provides information and resources to help you make this a smooth transition, and has partnered with Complete Practice Resources to provide you with an affordable online project management tool to help walk you through each phase of the necessary preparation to ensure you're ready. Learn more at $A A N$.com/view/ICD10 and start your transition today!

\section{Increasing the Value of YOUR AAN Membership}

FREE MOC Benefits Starting January 1, 2015

You asked and we listened. As of January 1, 2015, your robust AAN membership package includes FREE* access to online learning programs designed specifically to help you take the necessary steps toward fulfilling your maintenance of certification (MOC) requirements as mandated by the ABPN: NeuroPI ${ }^{\mathrm{SM}}$, NeuroSAE ${ }^{\circledR}$, NeuroLearn $^{\mathrm{SM}}$.

Learn more at $A A N$.com/view/MOC

* \$0 purchase price excludes Student members and Nurse Practitioner/Physician Assistant members at the lower dues rate. Free access is limited to one course per program at a time.

\section{American Brain Foundation Seeking New Public Board of Directors Members}

The American Brain Foundation (ABF) is seeking a maximum of five new public members for its Board of Directors who share a commitment to the ABF's mission, vision, and strategic direction. The Board of Directors is looking to transition from a predominantly AAN member neurologist makeup to a board composed largely of members of the public who bring a high level of skill and experience to the organization, and an ability to give or get donations.

If you know someone who would be well suited for this position please encourage them to apply at abf.convio.net/bod. Application deadline is July 1, 2015. For questions, please contact John Hutchins at generalcounsel@americanbrainfoundation.org. 


\section{Neurology}

\section{Cerebral proliferative angiopathy: Rare case of seizures, bone erosion, and pulsatile head bump}

Geeta Anjum Khwaja, Vikram Bohra, Ashish Duggal, et al.

Neurology 2015;84;2462-2463

DOI 10.1212/WNL.0000000000001686

\section{This information is current as of June 15, 2015}

\section{Updated Information \& Services}

Supplementary Material

\section{References}

Subspecialty Collections

Permissions \& Licensing

Reprints including high resolution figures, can be found at: http://n.neurology.org/content/84/24/2462.full

Supplementary material can be found at: http://n.neurology.org/content/suppl/2015/06/13/WNL.0000000000001 686.DC1

This article cites 2 articles, 1 of which you can access for free at: http://n.neurology.org/content/84/24/2462.full\#ref-list-1

This article, along with others on similar topics, appears in the following collection(s):

All Cognitive Disorders/Dementia

http://n.neurology.org/cgi/collection/all_cognitive_disorders_dementia All Imaging

http://n.neurology.org/cgi/collection/all_imaging

Arteriovenous malformation

http://n.neurology.org/cgi/collection/arteriovenous_malformation

Other cerebrovascular disease/ Stroke

http://n.neurology.org/cgi/collection/other_cerebrovascular_disease_st roke

Information about reproducing this article in parts (figures,tables) or in its entirety can be found online at:

http://www.neurology.org/about/about_the_journal\#permissions

Information about ordering reprints can be found online:

http://n.neurology.org/subscribers/advertise

Neurology ${ }^{\circledR}$ is the official journal of the American Academy of Neurology. Published continuously since 1951, it is now a weekly with 48 issues per year. Copyright (C) 2015 American Academy of Neurology. All rights reserved. Print ISSN: 0028-3878. Online ISSN: 1526-632X.

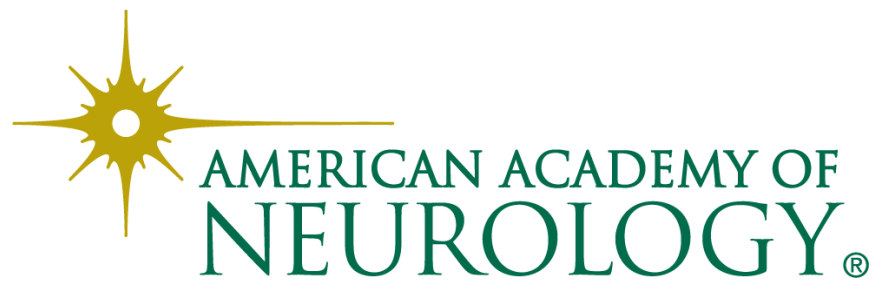

